Comparative Philosophy Volume 6, No. 1 (2015): 111-128

Open Access / ISSN 2151-6014

www.comparativephilosophy.org

\title{
HEIDEGGER AND INDIAN THINKING: THE HERMENEUTIC OF A "BELONGING-TOGETHER" OF NEGATION AND AFFIRMATION
}

\author{
JAISON D. VALLOORAN
}

\begin{abstract}
According to Heidegger the questioning of Being is unique to western philosophical tradition, however we see that the hermeneutic of Being is explicit in intercultural context of thinking. Understanding Brahman as "one" and "the same" Śankara speaks together with Heidegger the same hermeneutic of ontological monism. Due to the reason that there is no explicit terminological equivalent of the word 'Being' in Śankara's thinking, the hermeneutic of Śankara's ontological understanding of Brahman and its distinction as "Saguna" and "Nirguna" are not sufficiently explored. In an inter-cultural ontological context, it is important not to insist on terminological equivalence, but to search for hermeneutic depth. Similarly Madhyamaka-Buddhism of Nāgārjuna describes the universe as totally devoid of reality, called 'Śünya' or void, which is an expression of nihilism; it is comparable to Heidegger's observation of the concealing of Being as "nihil". The hermeneutic of these explicit ontological characters of Being, as concealment and unconcealment allow us to discover a sabotaging brotherhood, because the nihil and something are ontologically two essential sides of the same thinking.
\end{abstract}

Keywords: Heidegger, Śankara, Nāgārjuna, Inter-cultural Ontology, Indian Philosophy

\section{INTRODUCTION}

Philosophies give explanations of the world, of "what" of beings, and set norms for the right relationships between human beings. Therefore it is an exclusive property of mankind; still it is an intellectual engagement in an individual culture in its highest level. And language is the expression of this cultural impact, hence the medium of philosophizing. Inspired from Jaspers' understanding of axial age ['Weltachse'] Mall attributes the origin of philosophy to India, China and Europe (Mall 1989). However, the new globalized world becomes increasingly inter-cultural, i.e., the thinking itself turns out to be inter-cultural; as the result the thinking initiates the necessity of an "inter-cultural philosophy". It is a global attempt and necessity, aroused from the

VALLOORAN, JAISON D.: Former Teaching Faculty in Philosophy, Indian Institute of Technology Kanpur, India. Email: jvallooran@gmail.com 
need of integrating other cultures into one's own philosophical thinking and thus creating an intercultural perspective, rather mere comparison of existing ways of thinking. Nevertheless, the philosophies always wanted to consider ontological, epistemological, and ethical questions relatively independent from their own cultural environments. These contrasts become clearer, when the thinkers like Heidegger terms the metaphysics, nihilism and etc., as exclusive properties of western philosophical tradition. Simultaneously he advocates 'the thinking' as an activity of mankind around the world. Hence, the hermeneutic becomes increasingly relevant in the realm of thinking.

Etymologically speaking the term 'hermeneutics' is derived from the Greek word

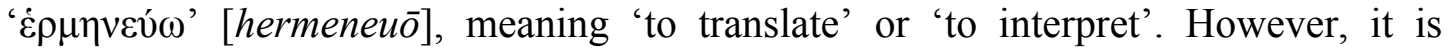
widely accepted that the term ' $\dot{\varepsilon} \rho \mu \eta v \varepsilon i ́ \alpha$ ' [hermeneia] was introduced into philosophy through the well-known title of Aristotle's work 'De Interpretatione' [On Interpretation]. Henceforth, we step into the horizon of interpretation, which also stands in relation with the folk etymology. According to the Greek mythology, Hermes ['E $\left.\rho \mu \tilde{\eta} \varsigma^{\prime}\right]$, the 'messenger of the Gods' brings the 'message', thereby he mediates between the Gods and between the Gods and men. For him, the inherent message was of primarily importance, which is obviously a question of interpretation of the coined words. Based on this, the early Greek view on language was formed, i.e., the language, consisting of signs is able to lead to truth or to falsehood. Similarly, Socrates proclaims that the words have the power to reveal or conceal and can deliver messages in an ambiguous way (Hoy, 1981). This is the context, where the hermeneutics, as the conditions of possibility for symbolic communication as such, enters into philosophical thinking. This is also the basis of our use of the term as well as the basis of ontological turn in hermeneutics in the mid-1920s, which was elicited in thinking by Heidegger's 'Sein und Zeit' and later explored further by Hans-Georg Gadamer and so on. Subsequently, hermeneutic becomes a task in thinking, i.e., to explore the deepest conditions for symbolic interaction, which is able to go beyond the barriers of culture, consequently the barriers of technical terms in language. In an intercultural context, such a hermeneutic of philosophical questioning turns to be the tread that binds every philosophical engagement of human beings around the world. The hermeneutic of thinking is multi-facetted; it is capable of answering to the needs of the polylogues in fields of systematic questioning in philosophy and simultaneously it presents itself as a valid alternative to euro-centrism and the separatism of philosophy. Moreover this is a historic-critical method, which creates fresh views on the history of philosophy in comparison with similar thinking. Therefore, so many are the proponents of this globally emerging dimension of thinking, such as Raúl Fornet-Betancourt, Heinz Kimmerle, Ram Adhar Mall, Franz Martin Wimmer, Jacques Derrida and so on.

Taking into account, what has been historically [first] put forward, the terms like 'metaphysics, ontology and epistemology' are undoubtedly the exclusive properties of western thinking. However, apart from this historical belongingness Heidegger recognizes an intrinsic conceptual relation of such terms with western thinking. It becomes explicit in Heidegger's attempts to understand, thereby also to criticize the 
metaphysics and nihilism as the sole product of western intellectual tradition. In this sense, it is not an exaggeration to note that the contemporary thinking in India lets itself often to coin in terms of western set standards, for, the Indian thinking is categorised frequently under the terms like metaphysics, ontology, epistemology and so on. ${ }^{1}$ Thereby, it is forgotten that we frame the originality of a particular thinking in terms of set norms and standards of the west, for which this thinking is not created. Hence, it becomes relevant that the hermeneutic of thinking is to be asserted, not the translations of set standards, for, translations are the interpretations of a particular cultural experience in the frame of another culture. For example, the question of being and the term 'Being' is of course an exclusive property of western thinking. The thinking in India never experienced being as experienced by Aristotle in his "science of being qua being" or in Platonic perplexity about 'being and non-being' or as an explicit counterpart to Wolf's conception of 'ontology'. However Halbfass (1993) asserts that the conception of Being in its very original sense plays an essential and undeniable role in Indian thought (Halbfass 1993, 21), whether it is called 'Brahman' or 'Sat'. In the long tradition of western ontological thinking we see a unique attempt of reintroducing the question of Being in the works of Martin Heidegger, especially at the beginning of his celebrated work Being and Time. According to Heidegger (2001), since its origin, the fundamental question of philosophy is nothing but the question of Being. He argues further, the long history of western ontological tradition since Plato and Aristotle is based on prejudices against the understandings of Being (Heidegger 2001, 02) that the ontological understandings since Plato and Aristotle consider Being, as the 'Highest', i.e. causa prima, the cause of all the beings. To be the 'Highest' means, to enclose all the attributes of time and space in its highest level; it should be then the superlative, the perfection. Due to this most general character, the question of Being remains for Heidegger primarily unexplored in the long history of western ontology. Therefore Heidegger describes in his Being and Time that the fundamental question of Being remains forgotten [die Seinsvergessenheit] (Heidegger 2001, 02).

According to Heidegger Being can be understood neither in the horizon of time nor in the horizon of space, because Being should form the fundament even for space and time. The beings are on the other hand understood in the horizon of time and space. Therefore, Being is neither eternal nor non-eternal; Being is neither something nor nothing; Being is not the creator, nor the superlative, nor the perfect being. It is evident that the conventional ontology understands Being often as causa prima or as causa sui, then the conventional ontology perceives Being in the horizon of time and space. This understanding of Being as causa prima or as causa sui is the typical

\footnotetext{
${ }^{1}$ Simultaneously it is also to be noted that the critics point out that the reception of terms from other culture background is a process of development, i.e., the language grows by adapting such terms, which can be cross-traditionally jointly concerned and can be addressed from distinct perspectives from different traditions. Accepting this view and its necessity in the process of growing, the point of our concern is concentrated on the growing tendencies of neglecting the vital cultural background of a term, while translating this into an alien cultural framework. In other words in such translations the inherent hermeneutic of a term gets neglected, while the words are getting translated.
} 
character of western metaphysics. Then, what is Being? Heidegger understands Being as "one" and the "same" and to be this whole pervasive "one" and the "same" means, to comprise the "nihil" and "something". Subsequently, it goes beyond the fundamental dividing norms of negation and affirmation, i.e., the categorization; this is the "belonging-together" of Being and the thinking, which is implicit in the western tradition since Parmenides. Hence, Heidegger (2006) asserts the "belonging-together" ["Zusammengehören"] of Being and human being [Sein und Da-sein] (Heidegger 2006, 37), which goes beyond any hierarchy or categorization. In terms hermeneutic of intercultural ontological thinking, it is the same "belonging-together", that Śankara assertively proclaims as the "A-dvaitam", i.e., the 'Non-duality' of Brahman and Ātman.

The term Being is western, and there is no explicit equivalent to this term in Indian thinking, other than the two different Sanskrit synonyms for the Greek word

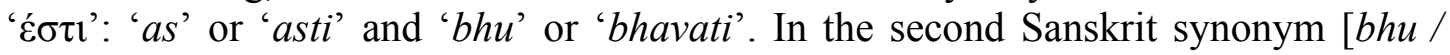
bhavati], Halbfass (1993) points out a fascinating etymological affinity with the

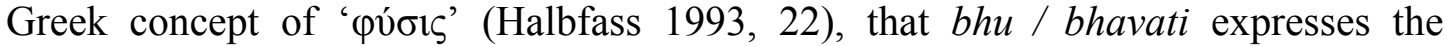
potentiality, i.e., the becoming. This is similar to the becoming of a blossom, which Heidegger understands under Greek concept of ' $\varphi v ́ \sigma ı \varsigma$ '. But in Indian thinking, both these synonyms are rarely understood in the sense of ' $\alpha-\lambda \eta \dot{\eta} \theta \varepsilon 1 \alpha$ ' or ' $\lambda$ ó $\gamma \circ \varsigma^{\prime}$ ', as the Greek understood the word ' $\varepsilon$ $\sigma \tau$ '. Hence, it is the hermeneutic, i.e., the hermeneutic of Being as 'one' and 'the same', as 'nihil' and 'something', which goes beyond any categorizations of time and space or the subject object relationship that plays a central and pervasive role in Indian thinking, especially in Śankara's understanding of Advaita-Vedānta, whether it is called "Brahman" or "Sat'.

\section{THE CONVENTIONAL ONTOLOGY: BEING BENEATH TIME AND SPACE}

According to Heidegger those prejudices against the concept of Being since Plato and Aristotle are based on the partial understandings of Being and on various attempts to define the concept of Being in the history of philosophy. In the history of western philosophy Being is rightly understood as the most general and therefore the emptiest term. According to the Greek and scholastic Logic, a definition is only possible, if the defined-something can be differentiated and further be specified. However, Being as the most general term, allows room neither for specifying nor for differentiating, i.e., Being does not allow any definition. It also means, that our Logic, which is based on the methods of induction and deduction, is not applicable on Being, but on beings alone. Being remains as the most general and therefore indefinable term that everyone understands in this or that way. Hence, the question of Being remains for Heidegger (2001) primarily unexplored in the history of western ontology. Consequently, Heidegger describes in his that the fundamental question of Being remains unattended and forgotten (Heidegger 2001, $02 \mathrm{f}$.).

According to the ontological understandings since Plato and Aristotle, Being is considered to be the "Highest", i.e. causa prima, the cause of every beings. In the 
language of religion this 'causa prima' is 'God'. Therefore in the traditional and middle-age ontology Being is identified primarily with God, as 'causa prima' or as 'causa sui' or as 'ipsum esse subsistens'. This identification of Being with 'causa prima' or with 'causa sui' is explicit in the ontological proofs of St. Anselm, where he comes with his profound arguments to prove the necessary existence of God, as the ontological highest. However, this understanding of Being that Being is the highest something or Being is the perfection of every relative existence, comes in Nietzsche's thinking to its necessary end. In Nietzsche's thinking (1977), God is dead; the famous, as well as notorious words from Nietzsche proclaim: "God is dead, we have killed him. You and I are his murderers" ["Gott ist tot, Wir haben ihn getötet. Ihr und Ich seid seine Mörder”.] (Nietzsche 1977, 125 f. and Heidegger 1980, 250). What do these words from Nietzsche ontologically mean? Of course, it means that metaphysical God is dead and nothing more, if we do not explore it further.

In those words, we see primarily a proclamation that "God is dead". Nietzsche does not stop there; he goes on screaming, "we have killed him". Does Nietzsche want to assert the same fact by repetition? No, on the other hand, he proclaims that it is not so; that the almighty God himself is disappeared from his pervasive presence, but he was killed by human (Seubert 2000, 186). Then Nietzsche asserts by repeating that you and I have killed him. It is to be noted that Nietzsche does not want to assert the fact, that God is dead, but the fact that he was killed. It means first of all that you and I are capable of killing God. To kill someone means, to be able to exercise power on him; and the human being is able to exercise power on God. This ultimate power, which provides the human being the supremacy over God, is the recognition that the very concept of God is a creation of human intellect. According to Heidegger's thinking (1980), Plato with his concept of an ideal world paved the way for God in philosophy; this is the philosophical turning point, where the Greek ontological beginning turns out to be metaphysical. Nietzsche asserts the same that God sovereigns the philosophy since Plato; and the human being, who is able to go beyond the concept of God, is named by Nietzsche as "Übermensch" [Superman] (Heidegger 1980, 250-251). Secondly, Nietzsche's proclamation pre-supposes a time without God, i.e., God is for Nietzsche no more eternal. It means ontologically, the concept of God is understood in the horizon of time, i.e. the 'time' becomes more fundamental than God. Thirdly, the proclamation "God is dead" means that the negation [Nihil] is in God itself. Ontologically speaking, this is the historical moment, when Being becomes explicit as nothing [ Nihil] and as something, consequently negation and affirmation are in Being itself; they are the two sides of the same coin.

Therefore, Heidegger understands in those words of Nietzsche not the God of religions, but the long-established understandings of Being as causa prima and as causa sui. If Being is understood in the horizon of time, it is no more Being, but only a being, perhaps the highest being [das höchste Seiende]. God understood as causa prima or as causa sui can be conceivably this highest being, but not Being. Being can be understood neither in the horizon of time nor in the horizon of space, because Being should form the fundament even for space and time; if not, it is not Being. The beings are on the other hand understood in the horizon of time and space. For this 
reason, Being is neither eternal nor non-eternal, Being is neither something nor nothing; in terms of Indian philosophy it is netti netti, [not this, not this]. The conventional ontology understands Being often as causa prima or as causa sui; subsequently it understands Being in the horizon of time and space. Even though the eastern thinking is framed neither in terms of western metaphysics nor in terms of nihilism, it is the same "highest something", that is understood by the term 'Saguna Brahman' [Brahman with qualities], because all qualities are ultimately the qualities of time and space.

\section{THE "BELONGING-TOGETHER” [“ZUSAMMENGEHÖREN”]}

Heidegger attempts in his Being and Time to reintroduce the ancient Greek understandings of Being [Parmenides], so that the modern thinking may be able to overcome its nihilistic inclinations by overcoming the metaphysical, traditional concept of Being as causa sui. According to Heidegger, what is explicit in Nietzsche's denial is the understanding of Being as Nihil, Being as nothing, i.e., the nothingness of Being. In the pre-Socratic ontological understandings 'Nihil' was immanent in the thinking of Being, but later, since the beginning of Platonic metaphysics this vital all-encompassing understanding of Being was forgotten, because the metaphysics understood Being as the superlative alone, as the highest of positives. Therefore reckoning with the pre-Socratic understandings on Being Heidegger (2006) aims at reintroducing the phenomenon of Being as a new beginning for thinking, where he asserts the "belonging-together" ["Zusammengehören"] of Being and human being [Sein und Da-sein], (Heidegger 2006, 37) as seen by Parmenides. According to Heidegger's Parmenides interpretation the thinking and Being belong together and it is the same and belongs to the same (36). It is the fundamental teaching of "belonging-together" at the beginning, that Parmenides asserts Being and thinking [thinking denotes the thinking being, i.e. human being] as the one and the same. According to Heidegger, the metaphysics understands 'belonging-together' as togetherness, where one is categorized under the other or vice versa; hence it paves way to the hierarchy, an order and an analytical system; this is the typical characteristic of the metaphysics, where Being cannot, but be only the highest (36-37). But in Parmenides the point of assertion was the 'belonging-together', which goes beyond any categorization, any order, i.e., the system building mechanism, that ultimately the thinking and Being are understood as the same! Therefore Heidegger interprets Being belongs to us, to the human, that Being and human being belong to each other, which brings the meaning of Heidegger's understanding of 'belonging-together' of Being and beings to its vital explication (40).

According to Heidegger (1993) in every translation the original cultural experience stays behind as non-transferable, because every experience of language is fundamentally an experience of its culture. Hence, in every translation the words are translated, but not the fundamental cultural experience behind the language (Heidegger 1993, 187). Therefore Heidegger insists that every phenomenological-

critical method must take this fundamental experience of language into account. The 
absence of such an experience is also evident in translating the German word 'zusammengehören' into 'belonging-together in English. The German word 'zusammengehören' is a combination of two words, 'zusammen' [together] and 'gehören' [belong]. Interestingly enough, the verb 'hören', means to 'hear' and the pre-syllable ' $g e$ ' is used to build its participle form, means the participle form of above-mentioned verb will be 'gehört'. It means the word 'gehören' [belong] stands in relation with 'hören' [hear] and these words have the word 'gehört' as its participle form. In this context, it is to be noted that Heidegger is attributed to have a pictorial presentation of the experience of 'belonging-together' in the idea of listening to something together, in which both listening parties meet as similar and equal partners. This notion of similarity and equivalence goes beyond any kind of categorization or system-building-mechanism of metaphysical thinking. The binding between these two parties is only the essential mutual belonging. This is how Heidegger understands the standpoint of Parmenides, when he asserts the "belonging-together". The metaphysics on the other hand stresses on 'zusammen', which denotes a belonging of something into something else. In such metaphysical 'belonging' [zusammen] the categorization, i.e., the fundamental feature of every system building mechanism, becomes explicit. In order to stress the togetherness [not the belonging] Heidegger (2006) writes the word 'zusammengehören' as 'zusammengehören' (Heidegger 2006, 38), subsequently he describes, in human prevails a belonging to Being, which belonging hears Being (39).

\section{4. ŚANKARA'S A-DVAITA [THE NON-DUALOTY] AND "BELONGING-TOGETHER"}

In terms of intercultural ontological thinking, it is the hermeneutic of same 'belonging-together' between Brahman and Ātman, that Śankara assertively proclaims as the "A-dvaita", the 'Non-duality'. The exposition of Śankara's Advaitam encloses the unconditional and difference-less unity of Brahman [the Absolute] and $\bar{A}$ tman [the individual self], where the individual self is nothing but the Absolute itself. However, it seems due to Avidya that the individual exists. The strict ontological conception of Brahman in the Advaita statement endorses Brahman as the 'one' and 'the same' that there is no room for differences. Brahman is difference-less in itself and the only true entity, subsequently Brahman is neither "Sajātìya" [homogeneous] nor "Vijâtīya" [heterogeneous]. The Advaita thinking illustrates simultaneously Brahman in ontological relevant terms like, truth [Sat], consciousness [Chit] and bliss [Ānanda] that the "Sat-Chit-Ananda" alone is accepted to be the positive expressions of Brahman; under all other conditions the ultimate Brahman is to be described as "neti, neti" [not this, not this] alone (Potter 1998, $15 \mathrm{ff}$ ). Understanding Brahman in positive and negative terms Advaita opens itself towards an ontological completeness, where the difference-less ultimate encompasses; this is where the mutual belonging between the absolute [Brahman] and the individual [Ātman] becomes prominent. 
However the western metaphysics, understanding Being as the highest being [das höchste Seiende] tends to categorize, that the 'belonging-together' of Being and Dasein as seen by Parmenides, is forgotten. The understanding of Being as the highest being pre-supposes the existence of lower beings, hence there is the hierarchy. In such hierarchy there is no 'belonging-together' in its original sense, but it is the categorization, which is the expression of system-building-mechanism. Subsequently in any attempt of categorization Being is no more Being in the sense of this belonging-together; categorization stands always for a hierarchy, the hierarchy of the highest being and the relative beings [das Seindeste und die Seiende]. One can here rightly argue that according to Śankara Brahman is pre-supposed for the existence of Jīva, but the existence of Jīva is never a condition for Brahman. Nevertheless such arguments are based on the perceived difference between Brahman and Jiva, i.e., in Vyāvahärika-sattā [empirical existence]; and one forgets that any such difference pervade in Pāramārthika-sattā [absolute existence]; there is the difference-less Brahman alone. However, point of critique should be understood from another perspective, that according to Heidegger the human being and Being are never one and the same in all its aspects; subsequently one is right to assume that Heidegger propagates an ontological monism and whereas Śankara advocates an absolute monism.

In Śankara's thinking, the hermeneutic of the question of Being plays undoubtedly a central and cardinal role than most of the philosophical streams in India. Nevertheless none of these systems including Advaita-Vedānta deals with the question of Being explicitly, due to the fact that this un-spelled phenomenon of Being is understood immanent in Brahman, immanent in 'Sat-chit-Änanda'. Hence the word 'Being' comes rarely in its explicit projection (Vallooran, 2013, 185); nonetheless the hermeneutic alone. Heidegger's understanding of Being goes beyond the time and space, hence it goes beyond all attributes. Researching on intercultural ontology, if it is not this un-spelled phenomenon of Being, what else shall we understand under the hermeneutic of Nirguna-Brahman, the very primary concept of something, that is immanent in everything and without any qualities of time and space? Ontologically speaking this conception of Nirguna-Brahman is nothing but the un-spelled understanding of Being! The hermeneutic of ontology stands assertively on a 'belonging-together' ['zusammengehören'], the 'belonging-together' of Ātman and Brahman; this is the advaitam, the non-duality, which goes beyond any categorization.

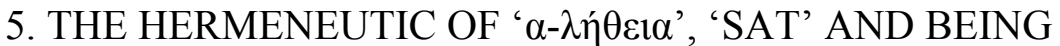

Every categorization pre-supposes a fundamental duality; essentially it is nothing but a subject-object-relationship; and every subject-object-relationship is nothing but the categorization. Such subject-object-relationship is the essence of metaphysics, which reigns the thinking since its origin in Plato's world of ideas. The human being that is tied up in the cave understood first of all the shadows for the sole reality. This is the first un-concealment of phenomenon. Once he turns back, he is able to see the world behind him in the light of fire, a further un-concealment. On search of the ultimate 
reality he makes himself free for a better sight. Finally he comes out of the cave and sees the sun and the world outside in the sunlight. According to Plato this is the ultimate un-concealment, the ultimate truth, the ' $\alpha-\lambda \eta^{\prime} \theta \varepsilon \iota \alpha$ ' (Heidegger 1975, 224). According to this narration, the human being must direct himself towards the higher truths of the sun, so that this ultimate un-concealment, and thus the ultimate truth may disclose to him. Heidegger recognizes two fundamental, metaphysical characteristics in this narration of Plato, i.e., there are twofold dependencies for Plato's understanding of truth. First, according to Plato the human being must direct himself towards the higher truth of the sun, so that the truth may disclose to him. This means any recognition of truth is result of human effort; this is the first problem of metaphysics that metaphysics set norms for human dealings. Secondly truth is that, which is revealed, i.e., mere un-concealment of phenomenon. In the Greek origin, especially Parmenides explores ' $\alpha-\lambda \eta \dot{\eta} \theta \varepsilon 1 \alpha$ ' as concealment and un-concealment. Reckoning with Parmenides Heidegger criticizes Plato's understanding of ' $\alpha-\lambda \dot{\eta} \theta \varepsilon \iota \alpha$ ' as mere un-concealment of phenomenon. According to Heidegger the term ' $\alpha-\lambda \eta \dot{\eta} \theta \varepsilon \iota \alpha$ ' is un-concealment and concealment as well. The Greeks have discovered the word $\alpha \lambda \eta \dot{\theta} \theta 1 \alpha$ for this revealing. The Romans translate this with 'veritas', that we say 'truth' and usually understand it as the correctness of an idea (Heidegger 1977, 10), and we in the context of Indian thinking understand this as 'Sat'.

Influenced by this metaphysical understanding of Plato, we proclaim something as true; if it is right, if the spelled out reality corresponds to the imagined or understood reality. Then the truth becomes a mere inter-relationship between our understanding and the verbally spelled out picture. Subsequently, ' $\alpha-\lambda \eta \dot{\eta} \theta \varepsilon 1 \alpha$ ' as concealment and un-concealment is reduced into 'right' and 'false', which is the matter of subjective perception and objective announcement alone [adaequatio intellectus et rei]. This is the sense of Plato's ultimate un-concealment, when the human being directs himself to the higher truth of the sun. The human being, who stands against the world of objects, is the subject, which is capable of knowing. Due to this unique metaphysical positioning of human being as the subject capable of knowing the world of objects, Heidegger assumes that the 'subject-object-thinking' rules the metaphysics, since Plato. Plato's understanding of the human being, who directs himself towards the higher truths of the sun, is the projection of human subjectivity in recognizing the truth. Since Plato, the metaphysics proclaims something to be true, if the spell out reality corresponds to the imagined or understood reality. Later in modern times we see that the same 'subject-objectthinking' rules the whole world of sciences in the form of "cogito ergo sum" that the thinking subject stands against the whole universe of objects. Heidegger recognizes in modern technique the ultimate expression of this 'subject-object-thinking', i.e., according to him the triumph of pervasive nihilism.

Restricting our thinking strictly to Indian philosophical tradition we understand the term 'truth' literarily as 'Sat'. 'Sat' is Being as well as truth in Indian thinking, that the term 'Satya' finds its etymological roots in Sat. Subsequently 'Sat' is not to understand in the sense of right and false, rather in the sense of concealment and unconcealment of the ultimate reality called Brahman. According to Advaita-Vedānta 
Brahman is understood as 'Sat-Chit-Ānanda' [Being-consciousness-bliss]. In the language of western ontology, Being as 'Sat' finds itself integrated and immanent in Brahman. If 'Sat' is understood in the sense of ' $\alpha-\lambda \eta \dot{\eta} \theta \varepsilon 1 \alpha$ ', it is eternal. However, if 'Sat' is understood in the sense of being right and being false, then at the end we have to declare that 'Sat' itself is subject to change, which cannot be the fact. Exploring 'Sat' ontologically the following aspects are evident:

(1) Sat is understood in Brahman, even though Brahman is understood as Sat and Sat is understood as Brahman. Undoubtedly Sat itself is Brahman, means further, that Sat and Brahman does not know any ontological difference, i.e. ontologically Brahman $\equiv$ Sat; and Sat $\equiv$ Brahman.

(2) Though there is an ontological equation between Brahman and Sat in absolute level [Pāramārthika-sattā] of reality, Sat is understood as under or immanent in Brahman in empirical level [Vyāvahārika-sattā], otherwise it may pave the way to duality. Then Brahman becomes the Saguna, understood in the horizon of space and time.

(3) Knowledge of Brahman is objective [Vedānta sūtra 1.1.3.]. So that a piece of knowledge could be understood as objective, it shall be expressive in words (Heidegger 1975, 126), i.e., is the Vedas. Heidegger (2001) expresses the same ontologically that the language is the 'house' of Being. And more interestingly Parmenides asserts, ' $\alpha-\lambda \eta \dot{\eta} \theta \varepsilon 1 \alpha$ ' and ' $\lambda$ ó $\gamma 0 \varsigma^{\prime}$ ' belong together (Heidegger 2001, 219).

(4) According to western ontological thinking the ultimate truth [' $\alpha-\lambda \eta^{\prime} \theta \varepsilon \iota \alpha$ '] is beyond the horizon of temporality. In Advaita-Vedānta 'Sat' is equal to eternal Brahman, means also beyond the horizon of temporality. ["Brahmasatyam, Jaganmithya, Jivo Brahmaiva na Aparah".]

(5) Analysing chronologically we see that the term 'Sat' and 'A-sat' appears in Rgveda for the first time, that the hymn of nassadīya (Rgveda X.129.) discusses over a time, where there was neither 'Sat' nor 'A-Sat'(Sprung 1995, 111). Later the Taittiriya-Upanishad describes, at the beginning there was only 'A-Sat' and interestingly enough the 'Sat' knows 'A-sat' as its origin (112), means, Nirguna Brahman is fundamental than Saguna Brahman. The understanding that 'Sat' is prior to 'A-Sat' is seen for the first time in Chandogya-Upanishad (112).

Inspired by the thinking of Parmenides Heidegger translates ' $\alpha-\lambda \eta \dot{\eta} \theta \varepsilon 1 \alpha$ ' ontologically as "un-concealment" [Un-verborgenheit]. Linguistically it is due to the fact that the Greek alphabet ' $\alpha$ ' in $\alpha-\lambda \eta^{\prime} \theta \varepsilon 1 \alpha$ is used as a privation. The hermeneutic of this privation is not explicit, if we translate and then understand ' $\alpha-\lambda \eta \dot{\eta} \theta \varepsilon 1 \alpha$ ' as 'truth'. Moreover, in such translation the hermeneutic of the concealing and un-concealing character of ' $\alpha-\lambda \eta \dot{\eta} \theta \varepsilon 1 \alpha$ ' becomes increasingly tributary. That is why Heidegger asserts on its ontological implication, i.e., to translate, subsequently understand ' $\alpha-\lambda \eta \dot{\eta} \theta \varepsilon 1 \alpha$ ' as 'un-concealment' [Un-verborgenheit]. Interestingly enough this Greek way of building privation by using the alphabet ' $\alpha$ ' is widely practiced in Sanskrit too. The very first example is the name 'A-dvaita', where the alphabet ' $\mathrm{A}$ ' stands for the privation of 'Dvaita'. So many are the examples, such as; »A-vidya«, "Advayam«, »Analpam«, "Avyayam«, and so on (Vallooran 2013, 169). 
Further, it is also to be noted, that Parmenides and Śankara (1949) assertively reckon, knowledge [Jnāna or Jnāna-mārga] is the only way of liberation. Śankara says, in his Upadesasahasri that the way of liberation is knowledge (Śankara 1949, 11). In his collection of poems Parmenides points out, that we the human being can follow only the way of wisdom. He further advises, we must keep ourselves away from ignorance (Kranz 1949, 93-95). Śankara aims nothing less, than keeping us away from "Avidya". According to Parmenides knowledge is Being; non-knowledge is non-being (93-95). Subsequently Parmenides and Śankara make a clear distinction between knowledge and non-knowledge. Both of them assert that we must keep ourselves away from non-knowledge. Due to such striking parallels between these two, Karl Reihnhardt (1959) writes, that Parmenides and Śankara show essential structural similarities (Reihnhardt 1959, 65). Moreover, Heidegger, Parmenides and Śankara assertively stand on a 'belonging-together' of Being and human being. According to Śankara it is the non-duality between Ātman and Brahman. According to Parmenides and Heidegger this is called as the 'belonging-together' of Being and thinking, i.e., the togetherness of Being and human being; the hermeneutic of 'belonging-together' ['Zusammengehören'] is also the teaching of Śankara, when he proclaims the 'Advaitam', i.e. the difference-less oneness (Vallooran 2013, 220).

\section{THE CONCEALING AND UN-CONCEALING CHARACTER OF BEING}

In Heidegger's essay (1962), 'The Question Concerning Technology', we see the "bringing-forth" in the sense of revealing stands not only for the artistic and technical activities, but also for a "bringing-forth-from-itself", interpreted in the sense of the Greek word ' $\varphi v ́ \sigma ı \varsigma^{\prime}$. Assuming that the ' $\varphi v ́ \sigma ı \varsigma^{\prime}$ is an act of 'bringing-forth-from-itself [which is also a 'bringing-forth'] shows the urge towards the 'efficient cause' [' $\lambda \varepsilon \dot{\gamma \varepsilon \imath v ', ~ ' \lambda o ́ \gamma o \varsigma ' ~ G e r m a n ~ ' U ̈ b e r l e g e n '] ; ~ a n d ~ u l t i m a t e l y ~ i t ~ s t a n d s ~ f o r ~ t h e ~ r e v e a l i n g ~}$ [Entbergen] character of Being (Heidegger 1962, 11.). Heidegger interprets Being in accordance with the Greek construction as a completed fact, that is determined differently than the metaphysical understanding. Hence, not only the handcraft manufacture, or the artistic and poetical bringing into appearance or concrete imagery

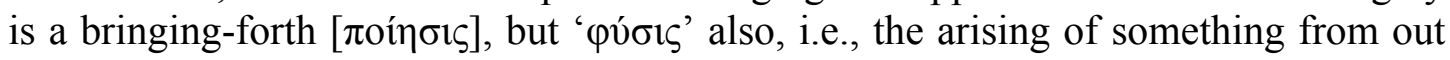

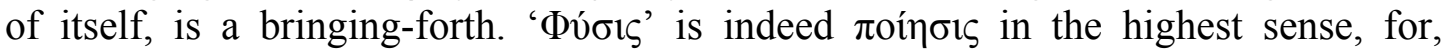
according to Heidegger what presences by means of ' $\varphi v ́ \sigma ı \varsigma^{\prime}$ has the bursting open belonging to bringing-forth. In contrast, what is brought forth by the artisan or the artist has to do with the presencing [An-wesen] of that, which at any given time comes to appearance in bringing-forth. So, according to Heidegger the bringing-forth brings hither out of concealment forth into un-concealment, that the bringing-forth comes to pass only insofar as something concealed comes into un-concealment. This act of coming into un-concealment rests and moves freely within, what we call revealing [das Entbergen].

Being, as void [nihil] is grounded in the essence of truth. According to Heidegger, what is explicit in the thinking of Nietzsche is nothing, but the ultimate expression of 
Being as "nihil", i.e., Being that bears its concealment with itself, hides itself in Nietzsche's thinking. This is the concealment of Being in beings, that Being finds itself in the highest stage of its metaphysical, historical character of forgetfulness, subsequently it becomes a metaphysical epoché, in which the thinking, especially Nietzsche's thinking is marked with this forgetfulness of Being (Heidegger, 1980, 253). The overcoming of nihilism means the un-concealment of these hidden characteristics of Being, which is essentially an overcoming of Platonic metaphysics. Nietzsche's conception of superman [Übermensch] is the highest expression of the concealing character of Being, for, he sustains the truth of beings as a whole. But this truth does not show straightforwardly, however it does reflect it off, as if in the art; this is the nature of superman, in which Nietzsche experiences Being as the "will to power" comes to its explicit expression. Subsequently, the essence of nihilism is not, what is explicit in the thinking of Nietzsche alone, but it rests in the history of metaphysics as the thinking of ' $i \delta \varepsilon \alpha$ ', as the denial of Being. In search of the essence of this immanent nihilism, we have to assert that the name 'nihilism' itself represents primarily a "nihil", a thinking, in which the "nihil" [nothing] becomes essential. Heidegger interprets nihilism accordingly, i.e., it is concerned with Being as nothing, that means, in its all aspects it is nothing; hence this is an experience of conceptualised emptiness. Heidegger argues further that the nihilism itself is founded in Being, for, nihilism is the story of the concealing of Being. In the history of metaphysics Being as something and as nothing comes apart into its dividend explored constitution. This is the essence of Being, which remains un-thought and undiscussed in nihilism, because nihilism as 'nihil' does not realize that the 'nihil' is to be understood also as a antonym of non-nihil (Heidegger, 1986, 44); subsequently they form the two inherent sides of the same thinking, marked with "revealing" [entbergen] and "concealing" [verbergen] characteristics of Being.

\section{THE CONCEPT OF ŚUNNYATA AND THE CONCEALING CHARACTER OF BEING}

Coming back to Indian thinking, the Madhyamaka school of Nāgārjuna describes the universe as totally devoid of reality, that according to them everything is called 'Śüny' or void. 'Śünya' or void is the explicit expression of 'nihil', that there are the nihilistic inclinations comparable to Nietzsche in certain perspectives. In many of the comparative studies, this Buddhist school, founded by Nāgārjuna is often described as being explicitly nihilistic; consequently a considerable amount of such studies depend on the superficial and apparent nihilistic characteristics of this school. This is due to the [mis] understanding of the term 'Śūnya' or 'Śñnyata', which is used to describe the indeterminable and indescribable reality in Madhyamaka school. In western nihilistic tradition, especially in the understanding of Nietzsche, the term nothing is a hypothetical possibility, that can neither conceived as a reality in the sense of ' $i s$ ' nor understood as a antonym of 'non-is'. Hence, it is a kind of conceptual emptiness, which would lead to nothing; a conceptualised 'nihil' alone. Every possibility of 
describing or understanding is unknown to this conceptual emptiness, that it can neither be affirmed nor be negated, because it is just 'nihil' alone.

It is evident that Nāgārjuna developed his theory of Śñnya-vāda from teaching of Buddha on dependent origination, called Pratitya-samutpāda. According to this theory the reality lacks Sva-bhāva, i.e., 'own nature'. In the context of explicit historical rivalry between Buddhism and Vedānta, it is also to be noted that Sva$b h \bar{a} v a$ is intrinsically linked with understanding Brahman in Upanishad, that according to them the [Saguna]Brahman is understood as the summum bonum, i.e., the perfection of Sva-bhāva. Buddhism, which rejects Brahman should subsequently assert on the lack of Sva-bhāva. Nāgārjuna comes forth with his dialectical brilliance to negate the conception of Sva-bhāva and thereby also the theories of Satkārya-vāda and the Asatkārya-vāda proposed by Sāmkhya and Nyāya schools respectively; and even Ajāti-vāda and Vivarta-vāda are essentially immune to Nāgarjuna's dialectics. The dialectical approach of Nāgārjuna pre-supposes explicitly the Pratityasamutpāda or dependant origination, that everything is originated depending on something else; that there is a cause for every effect and every cause is an effect of a previous cause. Therefore, everything is originated dependently, that there is no room for an eternal Sva-bhāva in the teaching of Pratitya-samutpāda. Lack of this Svabhāva is described as Śūnya. Nāgārjuna describes Śūnya in his Śūnyathasaptati that everything, -self, not-self, both self and not-self- being nameable thing, are like nirvāna, devoid of essential nature. Since there is no essential nature in things, causes and conditions, whether taken separately or collectively, everything is empty (E11; T24) (Potter 2002, 135). Further, Nāgārjuna asserts that Śūnya is itself Śūnya, that it lacks the Sva-bhāva. Does this mean that Nāgārjuna understands Súnya as conceptualized emptiness and subsequently holds a position comparable to Nietzsche?

The understanding of Nāgārjuna is not exactly about this conceptualized emptiness. Instead, the term Śūnya provided Nāgārjuna the best possible way to express on the real nature of intrinsic reality as such, that the intrinsic reality as such is understood as something that is indeterminable and indescribable. Hence, it is to be assumed in difference to Nietzsche that Nāgārjuna does not intend to deny the intrinsic reality as such, but the apparent phenomenal world perceived in terms of ' $i s$ ' and 'is-not'. According to Nāgārjuna, existence and non-existence, beginning and end, better and worse are not actual [tattva], but only practical ways of speaking [lōkavyavahāra] (E10; T24) (Potter 2002, 135). Hence, the term 'Śūnya' or 'Sünyata' stands for the expression of the ultimate reality, which cannot be expressed in terms of lokavyavahära, i.e., in terms of affirmation and negation. Subsequently, the understanding of Nāgārjuna on 'Śūnya' becomes something similar to the position of 'zero' in a mathematical scale; that positives and negatives are neutral to it. In context of an ontological exploration, it is important to understand that according to Nāgārjuna 'Śünya' is the best possible expression of intrinsic reality as such; hence the term 'Súnya' never denies the reality as such. Consequently the reality becomes something that is to be understood beyond the objectivity and referentiality, which can neither be perceived through the perspective possibilities nor understood through 
cognitive capacities. This reality, being devoid of phenomenal characters, is called Súnya or Súnyata.

In the opinion of S. Dasgupta, Nāgārjuna used the word 'Śūnya' or 'Śūnyatha' in order to designate both phenomenal and trans-phenomenal reality in a somewhat technical sense. He adds further that the world is called Súnya, because it is emptied or devoid of any intrinsic nature of its own [Nihsvabhāva] (Dasgupta 1998, 351-352). Hence the reality can neither be real, nor be unreal. The indeterminable and indescribable real nature, which is called Śünyatā or voidness, is then beyond the possibility of Nàma-rūpa. The Madhyamaka school of thought holds that 'Śñnya' is the transcendental reality [noumenon] behind the phenomenal one. Subsequently, 'Súnya' is free from change, from conditionality and from any other phenomenal characters. According to Potter empty [Śūnya] is a technical term for Nāgārjuna; when he calls something empty he is implying it doesn't really exist, but he is by no means suggesting that it doesn't seem to exist and that its functioning may well seem to occasion results such as misery and pain (Potter 2002, 15).

However Śunyata in its popular and apparent usage is something that is intelligible, i.e., in the sense of the negative aspect of ultimate reality, i.e., the description of 'what it is not'. The real nature of object cannot be established by the intellect and cannot, therefore, be described. For, that which is real, must be independent, i.e., should not depend on anything else for its existence and origination. According to S. Dasgupta, it is Śankara, who takes up the popular connotation of the word Sünya as 'nothing' while criticising the Ś̈nnya-vāda and consequently he condemns the expressive character of 'nihil' in 'Śunya-vāda'. Śankara argues that a philosophical position, which pictures the empirical world as a transitory show of non-substantial appearances [Śünya] is not even worthy of a criticism, because absolute unreality of sheer appearances without any underlying reality [Tattva] to appear is a self-defeating proposition, which cannot be defended by any instruments of valid cognition (Dasgupta \& Mohanta 1998, 351). Even though it might for the moment look as a misinterpretation from the side of Śankara, he as someone, who asserts the unity and realty of Âtman could recognise only the 'nihil' in the theories of Nāgārjuna. Nāgārjuna perhaps was not meaning to deny the existence of the ultimate reality as such; however it is also true that Nāgārjuna explores the 'nihil' of this ultimate reality, but not a nihilism as it is experienced by Nietzsche. Nietzsche experiences nihilism as 'nothing', not as the counterpart of something; he experiences nihilism in the pure sense of conceptualized emptiness of nothingness. Heidegger on the other hand understands essence of Nietzsche's thinking as something negative, as nihil, hence it becomes the concealing character of Being. The nihilism understood as the conceptualized emptiness of nothingness does not realize that the dividend exploring character of 'nihil' is also to be understood as an antonym of non-nihil (Heidegger 1986, 44). That is why Heidegger says, nihilism means, the essential incomprehension of the essence of nothingness and Nietzsche, the last metaphysical thinker, is caught in metaphysics and consequently not able to realise that nihil is an antonym of non-nihil. 
In its essence Śñnya-vāda can perhaps compared with the theory of relativity, that there is no thing, no phenomenon to be experienced or fixed. The absolute is independent character of its own Sva-bhāva, hence also beyond the Näma-rūpa, i.e., beyond any phenomenal description, which should be unconditionally true. Then there is nothing, metal or non-mental, which can be considered as real. Does this assumption mean that there is 'nothing', and the universe is understood in term of 'nihil', that even the values are not? In the sense of this ontological exploration S. N. Dasgupta (1998) is very accurate in assuming that Sankara's Brahman was very much like the Súnya of Nāgārjuna. For, it is difficult indeed to distinguish between pure being and pure non-being as a category (Dasgupta \& Mohanta 1998, 353).

\section{CONCLUSION}

The Advaita thinking can be claimed as metaphysical and the Buddhist thinking can be understood as nihilistic; nevertheless they strike a chord of hidden ontological possibilities, exactly the hermeneutic of Being. On the other hand, to experience the revealing and concealing aspects of Being in the thinking of Advaita and Buddhism demands an ontological destruction comparable to Heidegger's destruction of western ontology (Heidegger 2001, 2-3), so that the experience of Being may come to its phenomenological light, because the experience of those hermeneutic features of Being lays hidden in Indian thinking. But for a keen observer this hidden ontological experience is evident in various passages of Upanishads, such as Upanishads ask towards the 'Sat' of the Brahman. In such an expression, the 'Sat' is conceived independently of the divine principle of creation; consequently the hermeneutic of Being becomes explicit. To research such hidden possibilities and explore them is the intended obligation of this work; in the words of Heidegger, it is the destruction of conventional understanding of ontology; and every destruction intends and subsequently encloses a construction.

In the realm of the hermeneutic of Being, the Śūnya-vāda of Nāgārjuna and Śankara's understanding of Brahman are non-different; rather they are one and the same! What is explicit in the thinking of Nāgārjuna is then nothing, but the expression of Being as "nihil". In the history of Being, Being that bears his concealment with itself, hides itself in Nietzsche's thinking, as nihil. Heidegger understands nihilism as a thinking, in which Being becomes explicit as nihil, as the essence of Being, i.e., Being carries its oblivion with itself (Heidegger, 1980, 265). Hence the nihilism emerges itself as the concealing of Being in the thinking of Being and subsequently proclaims that with Being is also nothing, for, the nihilism as "nihil" does not realize that the "nihil" is to be also understood as an antonym of nonnihil (Heidegger 1986, 44). This is Heidegger's the thinking of Being; that Being is understood as "something" as well as "nothing", and subsequently is characterized with "revealing" as well as "concealing" features. The exploration of Śunya in the thinking of Nāgārjuna becomes ontologically similar to Heidegger's understanding of

nihilism. The reality is considered to be 'something' that shows the essence of existential certainty, where the counterpart of the same is also inherent. Ontologically 
this comes increasingly closer to the understanding of the revealing and concealing character of ' $\alpha-\lambda \eta \dot{\eta} \theta \varepsilon 1 \alpha$ '.

However, it is also to be noted that there is no watertight metaphysical distinction in Indian thinking as Heidegger discovers the dividend explored dichotomy of Being in western metaphysics. Nevertheless the hermeneutic of Being as nihil and something is integrated in Indian context. The western metaphysics is condemned by Heidegger, not because it deals with summum bonum, but because it understands Being as two dividend explored opposites of something and nothing. This may not be the absolute fact in Indian thinking, that we can find the thinking of something is integrated in the Ś̈nya of Nāgārjuna and the thinking of nihil is also integrated in the Nirguna-Brahman of Advaita. Still both of them represent somehow the hermeneutic of nihil and something respectively. Just as the concept of Śūnya of Nāgārjuna, the absolute reality [Paramärtha-sattā] of Advaita, which is known as Brahman goes beyond the reach of all concepts and conventions and remains un-contradicted. For this absolute reality, the Madhyamakas use the term 'advaya', whereas the Advaitins use the term 'advaita' and both surprisingly enough mean that the absolute is 'nondual'(Dasgupta \& Mohanta 1998, 354).

According to Heidegger, the comparisons as well as translations are always the explanations, i.e., they are the modes of transmission or deceptive appearance; therefore this attempt as any other comparative study is also not free of any such transmission, especially, when we discuss the thinking Śankara and Nāgārjuna under the set standards of western ontology and metaphysics. It is also to be noted, that any distinctive attempt to set a thinking under given standards and subsequently to compare with another thinking gives the impression that is still metaphysical. Likewise if we ask, what is the recognizable distinction between something and nihil, between Brahman and Súnya, then between Being and thinking, it is still metaphysical, because, to assert the distinction means to categorize under distinctive order; and any ontological research on 'belonging-together' must go beyond such metaphysical categorization. Here the conception of Śünya emerges having tremendous significance, as an attempt to go beyond the apparent metaphysical tendencies in Śankara's thinking. This work is not an attempt to compare or to classify two different thinking, but to understand the hermeneutic of the thinking of Being in its intercultural context and depth. In such an understanding the metaphysical distinction gets dissolved; the hermeneutic of 'belonging-together' stands beyond the terms, language and culture. This hermeneutic of 'belongingtogether' provides the foundation to ask the question of Being in Indian thinking, even if, there is no specified synonym for the western ontological term 'Being' in Indian thinking. The fascinating ontological aspects in the thinking Sankara and Nāgārjuna, subsequently in the thinking of Heidegger are based exclusively on this hermeneutic of "beloging-together". Of course, it is not about discovering the complete essence of equality or the total difference, but paying attention to the basic hermeneutic features, which make these two remote ways of thinking in the realm of Being comparable, without making the uniqueness of a thinking in the other dissolved. Hence, it is all about discovering the hidden ontological possibilities, which are 
covered by the ordinary modes of language, culture and further the science. Such an attempt finds its essential expansion in the field of hermeneutics and expresses the essence of any comparative attempt in thinking.

\section{ACKNOWLEDGEMENTS}

My heartfelt thanks to Prof. Dr. Claudius Strube for all his guidance, sharing of thoughts, and for introducing me to the core of Heidegger's thinking. My sincere thanks go also to the anonymous referees of this journal for their evaluation and comments.

\section{REFERENCES}

Dasgupta, Sanghamitra \& Mohanta, Dilip Kumar (1998), "Some reflections on the relation between Sankara and Buddhism", Indian philosophical Quarterly, 25 (3): 349-366.

Halbfass, Wilhelm (1993), Being and what there is: Classical Vaiśesika and the history of Indian ontology (Delhi: Sri Satguru publications).

Hartig, Willfred (1997), Die Lehre des Buddha und Heidegger (Konstanz: University Press).

Heidegger, Martin (1962), Die Frage nach der Technik (Pfüllingen: Günther Neske).

Heidegger, Martin (1980), Holzwege (Frankfurt: Vittorio Klostermann).

Heidegger, Martin (2006), Identität und Differenz (Frankfurt: Vittorio Klostermann).

Heidegger, Martin (1977), The Question Concerning Technology and Other Essays, translated and with an introduction by William Lovitt (New York \& London: Garland Publishing).

Heidegger, Martin (1986), Nietzsche: Der europäische Nihilismus (Frankfurt: Vittorio Klostermann).

Heidegger, Martin (2001), Sein und Zeit [Being and Time] (Tübingen: Max Niemeyer Publication).

Hoy, David Couzen (1981), The Critical Circle (University of California Press).

Kranz, Walter (1949), Vorsokratische Denker - Auswahl aus dem Ueberlieferten (Berlin \& Frankfurt: Weidmannsche Verlag).

Mall, Ram Adhar \& Hülsmann, Heinz (1989), Die drei Geburtsorte der Philosophie: China, Indien, Europa (Bouvier Verlag)

Potter, Karl H. (1998), Encyclopedia of Indian Philosophies: Advaita Vedānta up to Śankara and his pupils (Delhi: Motilal Banarsidass Publishers).

Potter, Karl H. (2002) Encyclopedia of Indian philosophies: Buddhist philosophy from 100 to 350 AD, (Delhi: Motilal Banarsidass)

Reihnhardt, Karl (1959), Parmenides und die Geschichte der griechischen Philosophie (Frankfurt: Vittorio Klostermann). 
Śankara (1949), Upadeshasahasri, translated and explained by Paul Hacker (Bonn: Ludwig Röhrscheid publications).

Sprung, Mervyn (Ed.) (1995), The question of Being: East-west perspectives (Delhi: Sri Satguru publications).

Vallooran, Jaison D. (2013), Heidegger und Śankara: die hermeneutische Zusammengehörigkeit von Ätman und Brahman (Hamburg: Publisher Dr. Kovač). 